\title{
HUSBAND AND WIFE UNDER FRENCH LAW: PAST, PRESENT, FUTURE
}

\section{André Tunct}

The revision of the French Civil Code by the Commission appointed in $1945^{1}$ is the subject of continuing and careful consideration by French lawyers. The discussions between members of the Commission, publicized by printing the Travaux préparatoires, ${ }^{2}$ find a broad audience among law practitioners and teachers. Although many points have been the subject of long argumentation, none of them has raised the same passionate debate as the problem of the organization of the family. The conflict between the views of the commissioners has been dramatized by the resignation of one of them, an outstanding law teacher, Professor Henri Mazeaud. When the Commission decided to abrogate the traditional rule, still written in the French Code, which states that the husband is "the head of the family," Professor Henri Mazeaud resigned and immediately stated the reasons for his act in an article which stands as a powerful dissent: "A Family Without a Head?" 3 The Commission remained unimpressed by the resignation and the article. The Avant-projet de Code Civil, which appeared in 1954, places husband and wife on a complete footing of equality, at least as far as their persons are concerned. ${ }^{4}$

The problem should not be considered moot, as some people think. The question is not merely one of stating or refusing to state the principle that the husband should be head of the family. From this principle, some important consequences follow. By one view, but not the other, the choice of residence of the family belongs to the husband, the wife being obliged to accept his decision unless authorized by the courts to live separately. By the same view, to consider only the main aspects

$\dagger$ Professor, Faculté de Droit, Université de Grenoble.

1. See Julliot de La Morandiere, The Reform of the French Civil Code, 97 U. PA. L. REV. 1 (1948) (Nadelmann transl.); cf. Nadelmann \& Von Mehren, Codification of French Conflicts Law, 1 AM. J. CoMp. L. 404 (1952) ; Niboyet, La question d'un nouveau Code Civil en France, 29 TuL. L. REv. 253 (1955).

2. Travaux de la Commission de Reforme du Code Crvil (7 vols. 1945-1951).

3. Mazeaud, Une Famille sans Chef?, [1951] Dalloz 141.

4. Avant-Projet de Code Civil Presente a Monsteur le Garde des Sceaux, Ministre de la Justice par la Commission de ReForme DU Code Civil art. 319 et seq. See also the Commission's ExPOSE DES Mortrs 105 (1954) and the translation by Dainow, Preliminary Report of the Civil Code Reform Commission of France, 16 LA. L. REv. 1 (1955). 
of the problem, the wife cannot engage in a profession against the will of her husband, again subject to appeal to the courts from her husband's decision. Moreover, even if the principle of predominance of the husband is rarely applicable as such, it would have a persuasive value: husband and wife would know that the wife should obey her husband if they disagree on certain points.

The problem of the organization of the family under French law shall be the subject of this article. The reader should remember, however, Portalis' warning: 'Laws . . . must be adapted to the character, to the habits, to the situation of the people for whom they are drafted." 5 The problem cannot be discussed as an academic one. Account must be taken of tradition and of French psychology. That is the reason why it is necessary to consider past and present French law before discussing its future. ${ }^{8}$

\section{The Past}

The status of the married woman, as it was at the eve of the drafting of the Civil Code, was the result of a combination of many factors. ${ }^{7}$ The first one was Roman law, which itself had experienced

5. Cf. Tunc, The Grand Outlines of the Code Napoleon, 29 TUL. I. REv. 431, 443 \& $n .41$ (1955).

6. This paper will consider only husband and wife as far as persons are concerned. It will not deal with the points on which equality is presently assured between husband and wife. It seems self-evident, for instance, that husband and wife owe to each other mutual fidelity, support and assistance. CoDE CIvII art. 212 (54th ed., Dalloz 1955). Such rules do not raise any discussion. For a comparative treatment of the organization of the family, see Arminjon, Nolde \& Wolff, TraIte DE DroIt CoMpare $\$ \$ 31,89,92,144-47,553,613,614,623,736,863,977,1016$ (3 vols. 1950-51); 2 TRAVAUX ET RECHERCHES DE L'INSTITUT DE DROIT COMPARE, LA CONDITION DE LA FEMME DANS IA SO-CIETE CONTEMrporaINe (Ancel ed. 1938); Dolle, L'egalite de l'homme et de la femme dans le droit de la famille, 2 Revue InTernationale de Droit CoMpare [hereinafter REv. INT. DR. CoMP.] 250 (France 1950); Un nouveau Code de la famille en Tchécoslovaquie, 2 Rev. INT. DR. CoMp. 701 (France 1950); Un nouveau Code de la famille en Bulgarie, 3 Rev. INT. DR. CoMr. 304 (France 1951); Tchirkovitch, Le code de la Fantille en Yougoslavie, 3 REv. INT. DR. CoMP. 616 (France 1951); Zajtay, Le droit du mariage dans le nouveau Code hongrois de la famille, 6 REv. INT. DR. CoMp. 491 (France 1954).

On the financial organization of the family, see Ancel in 2 Matrmonial PropERTY LAW (W. Friedmann ed. 1955); Solus, Mari et femme selon la loi du 22 Septembre 1942, 41 REvUe TRIMESTRIELLE DE DROIT CIVI 81 (France 1943); cf. Community Property Symposium, 15 LA. L. Rev. 509 (1955). For discussion of the provisions of the Avant-Projet, see Houin \& Verrier, The Legal Marital Property Regine According to the Projet of the French Commission for Revision of the Code Civil, 15 LA. L. REv. 712 (1955) ; Vasseur, La communaute legale et la communaute conventionnelle d'apres l'avant-projet de Code Civil, 53. RevUE TRIMEsTRIELLE DE DroIT CIVIL 407 (France 1955); Zajtay, Quelques projets de reforme du regime matrimonial legal en France, Belgique et Allemagne, 7 REv. INx. DR. Comp. 572 (France 1955).

For a sociological and psychological study of the family, see also CENTRE NATIONAL DE LA RESERCHE SCIENTIFIQUE, SOCIOLOGIE COMPAREE DE LA FAMILLE CONTEMPORAINE (1955); PRIGENT, RENOUVEAU DES IDEES SÚR LA FAMILLE (Institut National d'Etudes Demographiques Cashier No. 18, 1954).

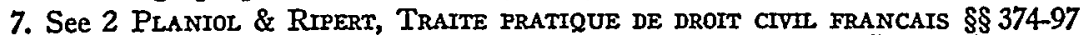
(2d ed. 1952); 1 Ripert \& Boulanger, Traite elementaIre DE DroIt CTVIL dE 
a long evolution. At its beginning, woman was placed by reason of her physical weakness under a perpetual tutorship. The only effect of marriage was to change her tutor: she escaped her father's authority only to be placed under her husband's. At the end of an evolution which we cannot describe here, woman was, on the contrary, entirely free, as long as she was no longer a minor; and marriage did not affect her capacity. Only very precise incapacities limited her rights. For instance, she could not make herself surety for her husband. This rule was laid down in $46 \mathrm{~A}$. D. by Emperor Claudius in order to protect her against an abuse of influence by her husband. This legal evolution, however, had not been accompanied by a similar evolution of habits. From literature, and even by what we still can observe in the rural classes of Italy or Corsica, we know that, as a matter of habit, the wife was usually kept under the very strong authority of her husband.

The second factor which influenced the status of the wife is the doctrine of the Roman Catholic Church, a doctrine shaped to a large extent by Saint Paul. Saint Paul, in accordance with the prevailing ideas of his time and those of the community, considered as a matter of course that woman was an inferior creature. (This is one of the reasons why she must cover her head before praying, while man may address God bareheaded.) This view was, of course, qualified by his sense of charity. The result is a beautiful-even though disputablecompromise, Saint Paul's epistle to the Ephesians, which is read to the new spouses at the marriage Mass. According to Saint Paul's views, the husband is the master of his wife and head of the family, but he is head as Jesus is head of the Church. He must love her to the point of being ready to sacrifice for her. To a certain extent, he is responsible for her and will answer for her to God. The concept, therefore, is very acceptable. It remains, however, that wives must be "submissive to their husbands . . . since the husband is the master of his wife."

German customs are the third and last factor which explain the status of the wife in Ancient France. Under these customs, while the unmarried woman was fully capable, the married woman was entirely

Planiol, $\$ 1777-1858$ (5th ed. 1953); 1 Julliot de LA Morandiere, Traite DE DRoIT CIVIL Francais de AMroIse Colin ET HenRt Capitant 649 (1953); 1 Mazeatd, LECONS DE DROIT CIVII 1086 (1955); 1 CARBONNIER, DROIT CIVII 353 (1955).

For a more detailed treatment of the matter, see 1 MONIRR, MANUEx EIEMENTAIRE DE DROIT ROMAIN 210, 212, 230 (6th ed. 1947); GIDE, ETUDE SUR IA CONDITTON PRTVEe de la Femine (2d ed. 1885); 2 Brissaud, Manuet D' Historre du Droit Francais 87 (1898); LEFEBVRE, LECONS D'INTRODUCTION GENERALE À L'HISTOIRE DU DROIT MATRXMONIAL FRANCAIS 395, 456 (1900); LE DROIT DES GENS MARIES (1908), LE LIEN DU MMARIAGE 346 (1913), LA FAMILLE EN FRANCE DANS LE DROTT ET DANS LES MMOEURS (1920); BONNECASE, LA PHILOSOPHIE DU CODE NAPOLEON APPLIQUEE AU DROIT DE LA IAMAIIIE (2d ed. 1928); VIALLETON, L'AUTORITE MARITALE SỤR LA. PERSONNE DE LA FEMME (1919). 
under her husband's power. Furthermore; in order to make the husband's power more effective, the married woman was placed under an incapacity: she could do no legal act without her husband's consent. This incapacity, however, was only a means to enforce the husband's power. In case the husband was away for a long time or deprived of his legal rights, the wife was automatically fully capable.

During the whole Ancien Regime, France was divided, as far as the status of the wife was concerned, into two parts. North of the Loire River, the customs had followed the German solutions; in the South, solutions of Roman law had retained their authority as the customary law of the provinces, but were to lose ground slowly under the influence of northern customs. In both parts of the country, furthermore, the weight of habit made women and, therefore, wives, quite inferior to men, while the Roman Catholic Church emphasized on the contrary, the duties of husbands towards their wives.

Although, as has been said, the northern customs were gaining ground at the end of the Ancien Regime, a reciprocal Roman law influence affected these customs. The revival of Roman law studies during the twelfth and thirteenth centuries led some legal teachers and writers of northern France to discover the wife's incapacity to be a surety for her husband. Attention was given to this rule at the end of the sixteenth century. The results were twofold. On the one hand, the rule was repealed by a royal edict of August 1606 . On the other hand, some legal writers, on the basis of secondary texts of the Roman period, explained it, not by the necessity of protecting wives against husbands' influence, but by the "weakness" of women as such ("propter inbecillitatem sexus"). "Weakness" was termed to mean mental as well as physical weakness, or, at least, lack of experience. The idea was historically wrong. It also ran contrary to logic: it would not have explained why only married women received protection, unless woman's consent to marriage be accepted as a token of her mental weakness-a very pessimistic view indeed. Nevertheless, the idea gained authority during the seventeenth century. In the eighteenth century, its authority was such that it was decided, contrary to the previous solution, that, if a husband was away for a long time, or insane, or deprived of his legal rights, his wife would not recover her capacity, and would not be able to do any legal act without authorization by the courts.

Therefore, at the eve of the Civil Code, two or three ideas were the basis of the wife's incapacity which was the rule-at least in the northern half of France; the necessity of keeping the wife under the husband's influence and the "weakness" of women. The idea of pro- 
tection against the husband's abuses of influence was not completely forgotten but was in the background.

The provisions of the Civil Code relating to the wife's status were drafted under the influence of Bonaparte, who clearly believed that women were very inferior creatures. His life as a soldier-and probably his shyness and his ambition-had reinforced the ideas that he had inherited from his birthplace, Corsica.

These ideas explain why a reinforcement of the traditional incapacity of the married woman may be found in the original provisions of the Code. The two basic provisions dealing with status of the wife are articles 213 and 217 . Article 213 reads as follows: "The husband owes protection to his wife; the wife owes obedience to her husband." Article 217 states: "The wife, even when she is separate in estate from her husband, cannot grant, alienate, mortgage, acquire, either by gratuitous or incumbered title, unless her husband concurs in the act, or yields his consent in writing." 8

Many provisions follow from these principles. "The wife is bound to live with her husband and to follow him wherever he chooses to reside; the husband is obliged to receive her and to furnish her with whatever is required for the convenience of life, in proportion to his means and condition." (Article 214).9 "The wife can not appear in court without the authorization of her husband, although she may be a public merchant, or possess her property separate from her husband." (Article 215)..$^{10}$

It appears, therefore, that the wife is placed under her husband's authority and furthermore made incapable. Since the unmarried woman is not incapable, the second rule must be explained by the first: the incapacity is only a means to make the husband's authority more effective. No other reason may be given for it. Evidence of the validity of this explanation may be found in Article 218: "If the husband refuses to empower his wife to appear in court, the judge may give her such authorization," ${ }^{11}$ and in Article 219: "If the husband refuses to empower his wife to perform a legal act, the wife may cause him to be cited to appear before the court, which may authorize her to perform such act, or refuse to authorize her, after the husband has been heard, or has been duly called to court." 12 Thus, a judicial authorization to appear in court or to perform a legal act is a protection for the wife

8. Cf. La. Crv. Cone AnN. art. 122 (West 1952).

9. Cf. id. art. 120.

- 10. Cf. id. art 121.

11. Cf. id. art. 124.

12. Cf. id. art 125. 
against an unreasonable use of authority by the husband. This confirms the hypothesis that incapacity may be explained only by this authority.

A departure from this justification of incapacity is found, however, in Article 222, which repeats the rule introduced in the eighteenth century: "If the husband is under interdiction or absent, the judge may, when satisfied of the fact, authorize the wife to appear in court or to contract." 18 This rule was as illogical under the Code as it had been originally. If an unmarried woman may appear in court or contract without any authorization, one fails to see why the same should not be true for a married woman whose husband is under interdiction or absent, especially since the appearance in court or the contract cannot, by reason of the legal matrimonial regime, have any financial repercussion on the husband. The same lack of logic may be found in Article 225: "Proceedings to annul the acts of the wife for lack of authorization can be instituted only by the wife or the husband or by their heirs." 14 One understands why the husband may obtain the annulment of an act which disregards his authority, but not why the wife may disregard her own signature when the husband would respect it.

\section{The Present}

The present law results from amendments made to the provisions of the Civil Code by statutes on February 18, 1938 and September 22, $1942 .{ }^{15}$ The statute of 1938 put an end to the incapacity of married women. It did not change, however, any rule of community property or any other matrimonial regime. Nor did it eliminate the husband's predominance over the wife. The drafters of the statute were satisfied in abolishing the duty of obedience previously expressed in Article 213 and in giving to the wife recourse to the courts against certain decisions which could be made by her husband.

The statute of 1942 is to a certain extent a continuation of the reform of 1938. Its main impact is upon the rules of the matrimonial regimes. However, it deals also with personal relations of the spouses. It further weakens the husband's supremacy and gives another wording to most of the Code provisions relating to family organization.

13. See also Code CrvIL art. 221 (54th ed., Dalloz 1955) ; cf. LA. CIv. Code ANN. art. 132 (West 1952).

14. Cf. id. art. 134.

15. On the present law, see PlaANIOL \& RTPERT, op. cit. supra note 7; 7 AUBRY ET RAU, DROIT CIVIL FRANCAIS \$\$ 471, 472 (Esmein ed. 1948); 1 RIPERT \& BOULANGER, op. cit. supra note $7, \$ \$ 1787-858 ; 1$ JULLIOT DE LA MORA NDIERE, op. cit. supra note 7 , at $662 ; 1$ MAZEAUD, op. cit. supra note 7 at $1008 ; 1$ CARBONNIER, op. cit. supra note 7 , at 342; Solus, supra note 6; Julliot de la Morandiere, La loi du 22 septembre 1942 sur les effets du mariage quant aux droits et devoirs des epoux, 1 JURIS-CIASSEUR PERTODIQUE 304 (1943). 
The present picture of the family organization under the Code is as follows. Article 213, since 1938, lays down the principle that the husband is considered "head of the family." That principle, however, was not directly stated in 1938 . It appeared first incidentally in a sentence governing the problem of the residence of the family: "The husband, head of the family, has the choice of the residence of the household . . . ." It appeared again in the third paragraph of the provision, stating the circumstances under which "the quality of head of the family would cease to exist to the benefit of the husband." The drafters of the statute of 1942 considered that this quality of the husband deserved to be stated as a basic principle and that, at the same time, the position of the wife should be made more precise. The present text is as follows:

"The husband is the head of the family. He exercises this function in the common interest of the spouses and the children.-The wife cooperates with the husband to insure the moral and material guidance of the family, to look after his living, to rear the children and to prepare them for their future.-The wife replaces the husband in his function of head of the family if he is unable to express his will by reason of his incapacity, of his absence, of his remoteness or for any other reason."

Whatever may be the merits of the proposed revision of Article 213-a question which will be discussed in part III of this paperthe value of the present version must be recognized. The theory is that since any human group needs an organ of guidance and decision, the husband is made the head of the family, by reason of his usually greater and broader experience. However, the wife is no longer the inferior creature conceived by the Romans and Bonaparte. She is associated with her husband to insure the management of the family. She is also an alternate for her husband. Nothing remains comparable to the rule introduced in the eighteenth century and embodied in the former Article $222^{18}$ for the cases of interdiction and absence.

The problem of the residence of the family is no longer dealt with in Article 214, as in 1804, nor in Article 213, as in 1938, but is now dealt with in Article 215 which, restating with more clarity the solution adopted in 1938, provides:

"The right to choose the residence of the family belongs to the husband; the wife is obliged to live with him and he is obliged to receive her. When the residence chosen by the husband presents for the family dangers of physical or moral nature, the wife

16. See text at note 13 supra. 
may, by exception, be authorized to have, for herself and for her children, another residence, decided upon by the judge."

The idea, therefore, is kept that the wife must "follow" her husband, even though the word is eliminated. However, the wife may be relieved from this obligation, for herself and her children, by judicial authorization, whenever the courts find it reasonable.

The principle of incapacity of married women stated in Articles 215 and 217 , previously discussed, ${ }^{17}$ and all its consequences as elaborated in the other provisions of the Chapter, are eliminated. The principle of full capacity is stated in Article 216: "A married woman has full legal capacity. The exercise of this capacity is limited only by the contract of marriage and by statutes."

A new provision expressly deals with the power of the wife to engage in a profession. Before 1938, the wife, being incapable of any legal act without her husband's authorization, could not engage in a profession. The principle was so clear that it was not even stated in the Civil Code. Only as far as commercial activities were concerned, was it expressed in Article 4 of the Commercial Code: "The wife cannot be a public merchant without her husband's consent." The abrogation of the incapacity of the wife would have led logically to a recognition of her power to engage in a profession. It was felt, however, in 1938, that the primary duties of the wife were at home and that the husband, as head of the family, should have control over his wife's activity. It was then stated in Article 216 that the husband would have the power to object to his wife's engaging in a separate profession. If, however, the objection was not justified by the interest of the household or of the family, the wife could be authorized by the court to disregard her husband's objection. This rule was not applicable to a commercial activity. Probably by reason of the danger of a commercial activity, as opposed to the activity of the wife as lawyer, physician, dentist or employee, the drafters did not change Article 4 of the Commercial Code.

By rephrasing the relevant provisions and changing Article 4 of the Commercial Code, the statute of 1942 goes further toward the wife's freedom concerning her activity. The principle stated in Article 223, section 1 is now that "the wife may hold a profession separate from her husband's profession, unless the husband objects to it." The principle is merely echoed in Article 4 of the Commercial Code: "The wife may be public merchant unless her husband objects to it." The rule should be respected by everybody. An employer cannot keep a 
wife among his employees, a Bar Association cannot keep a wife among its members and a court must refuse to consider her as a lawyer, nor may a Physicians' Association keep a wife among its members or permit her to exercise her profession, if the husband objects to her activity. Furthermore: "Obligations incurred by the wife in the exercise of this profession cannot be claimed against the husband by the persons with whom she contracted, if such persons had personal knowledge of the objection at the time they dealt with the wife." 18 Recourse is still given to the courts: "If the husband's objection is not justified by the interest of the family, the wife may be authorized by the judge to disregard it, in which case, the professional obligations incurred from the time of the objection are fully valid toward the husband." 19

Disregarding the other provisions of the Chapter, which relate to the powers of each of the spouses to perform a legal act, either on his own property notwithstanding the powers of the other spouse, or on the other spouse's property by means of a power of attorney or judicial authorization, ${ }^{20}$ it may not be difficult to observe the merits and the weakness of the present law.

Two merits must be recognized. First, the present law clears French law of the weight of a tradition which appears without justification today. The incapacity of a married woman, to the extent that it was not a means of reenforcing the husband's supremacy, was a mere historical misconception. As for the husband's absolute authority over the wife, it was a survival, or rather a resurgence, of ideas fought against by the Church from its very beginning and which are shocking to modern consciences. At the same time-and this is the second merit of the present law-the present system reasonably preserves the cohesion of the family by giving it a head and by precisely stating the respective responsibilities of husband and wife, whereas a mere statement of equality between them may permit a dissociation of the family.

The weakness of the law, however, is as obvious as its merits. In order to moderate the authority of the husband over the wife, permission is given to the wife to have recourse to courts, at least under certain circumstances. This recourse appears extremely dangerous. How can we conceive husband and wife litigating against each other and still keep the hope of maintaining them as members of a united

18. Conz CIVIL art. 223, $\$ 2$ (54th ed, Dalloz 1955).

19. Id. art. $223, \S 3$.

20. $C f$. articles cited in note 6 supra. 
family? It has been said that once they have learned the way to the courts, they will use it for divorce. Whether this prognostication is entirely true is disputable. The truth seems rather to be that recourse to courts is a remedy open only to spouses who are already on very bad terms. It cannot be a means to solve a special and temporary disagreement between happy spouses. It can be only a means to avoid excesses of power by a husband or excesses of liberty by a wife when the spouses are already in permanent and basic disagreement, whether they are already in litigation over a divorce, or ready to introduce a suit, or only living separately. As a matter of fact, the recourse to the courts is very exceptional. Although it may avoid some hardship, it cannot be a normal means to balance the husband's authority.

\section{The Future}

The drafters of the new Code were thus confronted with a very difficult task. ${ }^{21}$

The present system, which tends to establish the husband's moderately authoritarian control over the wife and the family, although not a failure, is far from satisfactory. The recourse to courts, as has been said, can work only as a very exceptional remedy, and is not free from dangers.

Nobody, of course, would advocate a return to the absolute authority established in 1804 . On the contrary, many people would be willing to state a complete equality between husband and wife, as between man and woman-equality not being synonymous with identity.

On the other hand, a complete equality between husband and wife may tend towards dissociation of the family. An example of the danger may be found in Soviet law. Complete equality is established by Articles 7-16 of the R.S.F.S.R. Code of Laws on Marriage, Family and Guardianship (1926), a typical provision being Article 9 which reads as follows:

"Both husband and wife shall enjoy full liberty in the choice of occupation or profession. The manner in which their joint household is conducted shall be determined by mutual agreement of the spouses. A change of residence by either husband or wife shall not oblige the other to follow." 22

21. On the conflicting views, see documents referred to in notes 3 and 4 supra; see also MAzEAUD, op. cit. supra note 7, at 1088 et seq.; La famille dans l'ordre juridique, 31 LES CASHIERS DU DROIT 37 (1954).

22. 2 Gsovsrr, Sovier CIVIL LAW 243 (1949). 
Of course, the fact that equality is accepted by Soviet law cannot be an argument for or against it. But one may ask what remains of our concept of a family if husband and wife are free to live miles away from each other. It is true that the family is now the object of much respect and attention from the Soviet government. ${ }^{23}$ It seems clear, however, that provisions such as Article 9 of the R.S.F.S.R. Code do not aid in the materialization of this new policy.

Facing the difficulties or the dangers inherent in any course of action, one first must recognize that the law is presently an instrument which cannot be delicate enough to govern the relationships between husband and wife as far as their persons are concerned. To establish an absolute authority of the husband over the wife, as did the Civil Code, was technically feasible. As soon, however, as the aim of the legislator is moderate authority, an authority founded only on the necessity to maintain the cohesion in the society formed between two partners-husband and wife, who are basically equal-the legislator cannot state any rule which would be applicable as a rule of law nor create any remedy which would be delicate enough not to create a danger of tension and dissociation between the two members of the society.

Having recognized this fact, one might be led to think that the legislator should take his hands off the problem. However, to abstain from stating anything would be-husband and wife being equal as citizens-to adopt impliedly the system of complete equality as it is under Soviet law. The problem cannot be escaped.

The problem may be considered from another point of view. "Laws," as stated by Portalis, "are not pure acts of will." The legislator must not consider in the abstract what he thinks desirable. $\mathrm{He}$ must also consider the habits and the desires of the people. However, from this angle, the problem does not appear clearer.

As a matter of fact, public opinion is certainly confused in France on the respective status of husband and wife. The husband's predominance is generally recognized. in some classes of France, especially in the rural classes and in the South. Currently, among workers, on the other hand, and quite often in the "bourgeois" classes, the wife is "the government" of the family. If the current opinions are considered, many people will be found in favor of the idea that, man and woman being equal, still husband and wife should not be equal because no society can endure without a head. This is, for instance, the opinion very strongly expressed by Professor Henri Mazeaud in the previously

23. See 1 id. at 111 (1948); Hazard, Law and Soctal Change in the U.S.S.R. 245 (1953). 
mentioned article. ${ }^{24}$ But it may be answered that, if an ordinary society cannot live without a head, the same is not true for the society of a husband and wife, not only because it is a society of two, but because mutual love makes common decisions and reciprocal adjustment of the personalities more facile. Being based on love, the husband and wife society may settle itself and consolidate itself without any head; the respective values and responsibilities of the spouses will establish their respective authorities.

Professor Henri Mazeaud also considers that the spouses who are members of the Roman Catholic Church or of most of the Reformed Churches must recognize the supremacy of the husband, according to Saint Paul's epistle to the Ephesians already noted. ${ }^{25}$ This view again is disputed. The Arcanum encyclic of 1880 and the Casti Conmubii of 1930 are much more elaborate and qualified than Saint Paul's epistle. Some Catholics consider that the only final aim of the Church in the organization of the family is the harmony between the spouses, and that predominance of the husband is taught only as the normal, but not necessary, means of obtaining harmony. Some of them even believe that the Church has played an eminent role in the emancipation of the woman and that, if tradition still gives the husband some predominance, the Church should continue to lead the way toward the possibility of a full opening of female personality, married as well as unmarried.

The drafters of the Avant-Projet were thus confronted with a baffling problem. If the solutions they gave are not perfect oneswe shall try to risk a judgment on them after having explained them - everybody will admit that they are a careful compromise, and to a certain extent, a happy reconciliation between the various views. The drafters had, of course, to make a basic decision on the problem of hierarchy or equality between spouses and they chose equality. But they worked out new rules clearly designed to avoid the dangers which might result from equality.

Article 319 of the Avant-Projet states, as does present Article 212, "Spouses owe to each other mutual fidelity, support and assistance."

Article 320 , on the other hand, is a complete departure from present Article 213. Even though it does not state equality as suchas a right given to the wife against her husband-it places husband and wife on an equal footing in the direction of the family:

"Spouses concur, in the interest of the family, to assure its moral and financial guidance, to raise the children and prepare 
them for their future. If one of the spouses is incapable, or if he is absent, or sentenced for desertion, the other exercises alone the authority mentioned in the first paragraph. The same will occur if one of the spouses voluntarily abandons the common life or is unable to express his will by reason of his remoteness or by any other reason."

With the desire of avoiding the dangers inherent in Article 9 of the R.S.F.S.R. Code, Article 321 states as a basic principle: "Spouses are held to live together." The principle is carried into effect as follows: "If they cannot agree on the choice of their common residence, each of them may, in the interest of the family, ask the court to decide where this residence will be or to authorize him to have a separate residence for himself and those of his children who shall be entrusted to him." The comparison with the present Article 215 is easy. While Article 215 leaves full freedom for the husband to reside where he chooses and obliges the wife to follow him, subject to her obtaining a judicial exemption, prospective Article 321 would permit each of the spouses to ask the court to decide on the family residence or to authorize him to have a separate residence. Equality between husband and wife would thus be obtained at the cost of an extension of recourse to the courts.

The same may be said of prospective Article 326, as opposed to present Article 223. The former reads as follows: "Each of the spouses may exercise the profession of his choice, unless the other spouse asks the court to forbid the latter, in the interest of the family, to exercise this profession." Again, this provision extends the scope of recourse to the courts. Again, it makes the husband lose his full freedom. As far as the wife is concerned, on the contrary, it weakens his control over her activity. While the husband may presently prohibit her from engaging in a profession, subject to her appeal to the court, the husband under the Avant-Projet would only be able to ask the court to prohibit her from exercising the profession.

A last consequence of the equality established between husband and wife may be found in Article 210 of the Avant-Projet, which provides: "Each of the spouses may use the name of the other, unless the latter, in the interest of the family, asks the court to prohibit the former from using his name." This provision has no precedent in the present Civil Code, but may be compared with Article 7 of the R.S.F.S.R. Code, according to which: "On registering a marriage, the spouses may declare their desire to use a common surname, that of either the husband or the wife, or to retain their antenuptial surnames." 28 
To express an opinion on the provisions which have just been reproduced may be, if presumptuous, a duty for the writer. In his judgment, the provision which deserves bitter criticism is also the least important. To state that "each of the spouses may use the name of the other" seems both unrealistic and ridiculous. The intention of the drafters as it appears from the expose des motifs ${ }^{27}$ was to permit the wife, according to the general custom, to use her husband's name, or to permit the spouses, as is sometimes done in certain provinces, to associate their names. This intention, if it was the only intention of the drafters, is completely betrayed by the wording of the provision. As the provision is now drafted, it permits each of the spouses to continue to use his own name. This practice would be contrary to the present one. The least that can be said is that it would not help cohesion of the family. While "false spouses" are careful to introduce themselves under the same name, "true spouses" might introduce themselves as "John A. and Mary B." Since the children bear the name of the father, they would not bear the same name as the mother. The spouses might also decide to adopt as a common name, the wife's name, which would be strange and possibly misleading for third parties. Furthermore, if the spouses have a very strong sense of humor, John A. might choose to become, by reason of his marriage, John B., while Mary B. would become Mary A. All these consequences may not be very serious for the family. They are at least unfortunate. It is submitted that it would have been better for the drafters, either to say nothing on the matter, and to leave it as it is now according to custom, or to state that the wife shall take her husband's name (which should not give her any inferiority complex) unless the spouses decide to associate their names.

Articles 326 and 321 will be the subject of much discussion, as they have been among the members of the Commission. It is submitted, however, that they do not create a serious danger for the family. Granted that the exercise of a profession by the wife may be more dangerous for the family than the exercise of a certain profession by the husband, nonetheless the wife is highly interested in the kind of activity which will be taken up by the husband, and she may have a better appreciation of the consequences of his activity for the family.

27. "According to the traditional custom, the project allows each of the spouses to use the other's name; but it extends the judicial rule which prevents the wife from using her husband's name when the husband disapproves of her exercising a liberal or artistic profession; from now on, each of the spouses will be authorized to ask the court, in the interest of the family, to prohibit the other from using his name (art. 210)." Commission de REFORMe dU CODE CiviL, EXPOSE des Motifs 84. 
This interest and this possibility of judgment should lead the husband to give great weight to the desires of his spouse and to her arguments. Obviously, it is highly desirable that the matter be settled between the spouses themselves. If, however, this appears impossible, should not the interest of the wife and children materialize in the possibility of recourse to the courts, unfortunate as this recourse may appear? Since most people will agree that the wife should not be free to engage in a profession and since the husband presently owns a veto power on her activity, subject to the final decision of the courts, is there a good reason not to give her, reciprocally, a certain control over the activity of the husband, at least through the courts? This recourse should be and will be very exceptional, as is presently the exercise by the husband of his veto power and the appeal to the courts by the wife. It may, however, be the last resort to avoid a very unfortunate decision, and it will oblige the husband to give greater consideration to his wife's arguments-it will increase her "bargaining power." Some judges even feel that they could play a certain role when serious decisions are to be taken by the household. They would like to have the opportunity to listen informally to the complaint of a spouse, to ask the other spouse, simply by letter, to come and discuss the matter with them -outside the court room and without any lawyer-and to try to lead the spouses toward the more reasonable solution. What has been said for the problem of choice of profession might be repeated for the problem of choice of residence. Both of them are quite often linked.

Finally, if a statement of the respective position of husband and wife must be made in the Code, the writer prefers the prospective Article 320 to the present Article 213. The question has been discussed whether it was necessary or even proper for the legislator to state a rule which could not be enforced by the courts. The writer believes with Professor Henri Mazeaud that the legislator should not remain silent on such a basic point as the respective positions of husband and wife, and that the rule he gives will be spontaneously respected by many spouses or at least will have an influence on their behaviour. He disagrees with Professor Mazeaud on the rule which should be stated by the legislator. Although a Catholic, as Professor Mazeaud, he does not consider, for aforesaid reasons, that the Church imposes a supremacy of the husband, even as a means of obtaining the harmony between the spouses. He considers, furthermore, that under the weight of Roman tradition and also by reason of their usually greater responsibilities, many French husbands, although of good will, show a certain pride and a certain authoritarianism which are a source of sufferings- 
sometimes more or less conscious-for the wives. If a principle must be stated which will have mainly an educational value, he feels that the best directive which may be given to the spouses is that they will concur in assuring the direction of the family. Such a directive will permit each spouse to gain the recognized authority he deserves in a certain field of problems. It will help toward a just and natural adjustment of the personalities. 